\title{
BLUE-RED REACHES THE END OF THE LINE AT NINE*
}

ERNIE KUYT, 3810-103 B Street, Edmonton, Alberta. T6J 2X9

In early May 1977, in the northeast corner of the Klewi rivermarshes, a tiny whooping crane chick kicked itself out of the shell, its "home" for almost a month. That year was a pretty good year for whoopers in Canada's Wood Buffalo National Park and 10 chicks survived the summer, most of them in the Klewi and Sass marshes and a few scattered elsewhere.

By the end of July when the northeast Klewi chick had reached about three quarters of its parents' size, a small aircraft came droning in from the south. As it reached the area where the whooping crane chick and its parents were feeding, the aircraft began circling at several thousand feet above ground. The cranes only occasionally glanced at the aircraft as it continued to make its lazy loops in the sky. There seemed little concern as the aircraft was well up in the sky and, after all, aircraft were frequently encountered by the birds.

Soon, however, a second noise was heard and a noisy helicopter landed near the birds. Minutes later the chick was caught by men emerging from the machine. The young crane was not hurt and shortly thereafter it was reunited with its parents. Now the chick carried a large blue band and a metal band high up on its left leg and a large red band on its right leg. From then on we knew the crane as "Blue-Red."

In November the three birds safely completed the fall migration to the Aransas National Wildlife Refuge in Texas and we presume the three cranes flew back to Wood Buffalo National Park the following spring. On 5 June 1978 I saw Blue-Red, then a year)old, with an unbanded bird in an area between Sass and Klewi rivers. It was an important sighting because for the first time we knew that yearling whoopers returned to the breeding area and were not, as suggested by some, "summer wanderers," which spend the summers inunknown areas in northern Canada. On 10 June the two birds were in the same area but on

11 July a third bird had joined, also banded (Green-Red) in 1977, and the three birds were again observed a week later.

Blue-Red wintered at Aransas in 1978-1979 and returned north where in May, June and July we saw Blue-Red and Green-Red in the same area as in 1978.

The two birds returned to Aransas in fall 1979 and the following spring (May 1, 3 and 5, 1980) we again encountered our friend Blue-Red. Now, however, the bird had a different companion, again an unbanded bird and also the area was different. Now the two birds were $5-8 \mathrm{~km}$ north of the northernmost nest (in the Nyarling area). It was tempting to think that the cranes were scouting out a new area and could return here in 1981 to nest.

The cranes however, did not return here in 1981 or at least we did not see them. Nor did we see them anywhere else in summer 1981. The following year Blue-Red and an unbanded bird were spotted on 10 and 20 May, again in the Nyarling area. This was encouraging for earlier we had learned (from observations of other banded birds) that males could successfully breed at four years of age.

* Reprinted from Nature Society News, Griggsville, Illinois. 62340 July 1986:14. 
To our disappointment the birds moved in May or June and on 16 June we saw them once more in WBNP, now back in the south end of the "non-breeder" area, an area so called because I had never found nests here.

That fall, on 23 September I saw BlueRed and an unbanded bird on Pelican Lake in southern Saskatchewan. It seemed very much that our former Klewichick had formed a pair bond with another bird and was wintering, summering and migrating with that bird. Studies at Aransas showed Blue-Red was most likely a male.

The following year, 1983, began disappointingly because we did not find BlueRed during the breeding season. But on 4 August, 1983, after the banding of young cranes had been completed, we sighted a family group with a single chick in the south end of the "non-breeder" area. Clearly this was a pair whose nesting activities had been undetected by us in 1983 - always a possibility in the vastness of WBNP. As we circled the three birds to get a better look at the chick we noted with pleasure that one of the adults was Blue-Red; its mate was unbanded.

In 1984 we did find their nest and removed one of the two eggs for shipment to Grays Lake National Wildlife Refuge in Idaho. The egg hatched but the egg left in the nest was addled. In 1985 neither of the two eggshatched and when this year's egg pick-up approached, I was firmly resolved to remove both of the birds' eggs and substitute one good egg so that the pair would have a reasonable chance to raise at least one chick.

When we landed near the nest on 24 May this year we were devastated to find Blue-Red lying dead on the nest marsh. Death had occurred only a day or so earlier and Blue-Red's mate was still incubating the eggs. We removed the dead bird and one of the two eggs and then, on the following day when it appeared the remaining crane was no longer attending the nest, we collected the second egg as well. One of the two collected eggs was no good but the second egg transplanted to Idaho, hatched and we hope that the chick will survive.

Blue-Red has been examined by the veterinarian-pathologists at the University of Saskatchewan in Saskatoon. The bird was in good condition although there was an indication of a heart muscle irregularity. Further tests of tissue samples may provide us with the answers why Blue-Red died at the relatively early age of nine years.

Although we regret losing a whooping crane, the evidence of poor quality of eggs (at least four of the pair's 7-8 eggs produced from 1983-1986 failed to hatch indicating perhaps a problem of infertility) meant that if we had to lose a bird, it would be better to lose Blue-Red than a known proven breeder.

Also, we were lucky, in a way, to get the dead bird in good condition or even to find it at all. As Blue-Red was a knownage bird its life history is far more detailed than we could have provided for an unbanded bird. 